Department of Emergency Medicine, Harvard Medical School, Boston, MA USA

2 Global Climate and Health Alliance, Berkeley, CA, USA

3 Department of Environment, Climate Change and Health, World Health Organization, Geneva, Switzerland

Correspondence to: R N Salas rnsalas@mgh.harvard.edu

Cite this as: BMJ 2021;375:n2960 http://dx.doi.org/10.1136/bmj.n2960 Published: 07 December 2021

\section{Health at COP26: just the beginning}

\section{An engaged health community is finding its voice, and being heard}

\author{
Renee N Salas, ${ }^{1}$ Jeni Miller, ${ }^{2}$ Maria Neira ${ }^{3}$
}

During the first two weeks of November, the global health community advocated on behalf of its patients and communities with historic engagement at the 26th UN climate change conference (COP26) in Glasgow, Scotland. The diagnosis of the climate crisis as a health emergency is clear given the extensive health harms, inequities, and healthcare system disruptions already present at warming of $1.1^{\circ} \mathrm{C}$ above pre-industrial levels. ${ }^{1}$ Every fraction of a degree matters. However, the agreements outlined by world leaders in the Glasgow climate pact are far from adequate to protect health, save lives, and advance equity. ${ }^{2}$

After a year's delay because of the covid-19 pandemic, COP26 was a pivotal moment to implement the 2015 Paris Agreement, when every country in the world committed to limit warming by 2100 to "far below" $2^{\circ} \mathrm{C}$, with a true goal of $1.5^{\circ} \mathrm{C}$. Without swift action by 2030, the $1.5^{\circ} \mathrm{C}$ threshold is likely to be breached in the next two decades. ${ }^{3}$ The COP 26 mantra "keep $1.5^{\circ} \mathrm{C}$ alive" can be interpreted as the difference between life and death for many people, given the accelerating health harms associated with climate change and growing concern about environmental tipping points .$^{3-6}$

\section{Prevention}

A key preventive health strategy is a swift reduction in greenhouse gas emissions, especially through an equitable transition away from burning fossil fuels. This avoids health harms related to climate change, and gains the near-term benefit of reducing air pollution-currently responsible for over seven million premature deaths a year. ${ }^{7}$ The $\mathrm{COP}_{2} 6$ agreement is the first to include the phasing out of coal and removal of fossil fuel subsidies, and although the agreement's language was weakened during final negotiations, many countries are likely to move quickly away from these harmful and outdated forms of energy.

In advance of $\mathrm{COP} 26,153$ countries submitted new or updated plans for reducing their greenhouse gas emissions by 2030, known as nationally determined contributions. ${ }^{8}$ Unfortunately, these commitments would only limit warming to a best estimate of $2.4^{\circ} \mathrm{C}$ by 2100 . Even the most optimistic scenario, with all announced targets met in full and on time, would result in $1.8^{\circ} \mathrm{C}$ of warming. ${ }^{9}$ Other key pledges include commitments by 104 countries to cut emissions of methane, a potent greenhouse gas, by $30 \%{ }^{10}$ and pledges by 141 countries to halt and reverse deforestation. ${ }^{11}$

\section{Treatment}

Adaptation is the Glasgow climate pact's headline treatment strategy, with commitments by high income countries (who have historically emitted most greenhouse gases) to fund adaptations in low income and vulnerable countries (where health and environmental harms are greatest). A recent World Health Organization survey showed that lack of funding is one of the main barriers countries face in implementing effective protection measures for their populations ${ }^{12}$; only $0.3 \%$ of global adaptation funding currently supports health systems. ${ }^{5}$

The $\$ 100 b n$ a year promised to vulnerable countries by 2020 failed to materialise, and even the COP26 commitment to double 2019 adaptation finance will fall far short of what is needed. ${ }^{813}$ Although some progress was made towards compensating vulnerable countries for unavoidable loss and damage, financial commitments proved contentious and discussion was largely postponed until next year's meeting.

The "right to health," as outlined in the Paris Agreement, had its most visible role yet as this was the first COP to include a health programme in the presidency portfolio. Over 50 countries committed to developing climate resilient, sustainable, and low carbon health systems in the COP26 health programme. ${ }^{14}$ Fourteen countries also committed to net zero deadlines for their health sectors by 2030 to 2050, joining the UK's existing 2040 commitment to a net zero NHS. The meeting also included a health pavilion run by WHO-hosting over 60 events-for the first time.

Health professionals increasingly recognise that the climate crisis challenges our foundational health mission of improving health, preventing harm, and advancing equity, and over 100 attended COP26. Attendees were emboldened by a "healthy climate prescription" on behalf of more than 46 million health workers around the globe. ${ }^{15}$ Unfortunately, nearly 500 fossil fuel lobbyists were also active at COP26. ${ }^{16}$

The health arguments for climate mitigation and adaptation are compelling, with important near term health benefits. ${ }^{1718}$ As the world already prepares for $\mathrm{COP} 27$, incorporating health into nationally determined contributions for 2022 will be critical to ensure that health becomes a motivation for action. ${ }^{19}$

A patient's progress is tracked through laboratory tests and vital signs. Similarly, the health community will hold global leaders accountable not by their words but by their results, tracked through objective metrics such as tonnes of carbon dioxide reduced, dollars invested in adaptations to protect health, and lives saved.

COP26 is just the beginning of massive engagement by the health community. We will not rest until countries respond to the climate crisis with the 
emergent prevention and treatment required to protect the health of our patients and communities.

Competing interests: We have read and understood BMJ policy on declaration of interests and have no conflicts of interest to declare.

Provenance and peer review: Commissioned; not externally peer reviewed.

We thank Arthur Wyns and Kelly Phouyaphone for their support.

1 Salas RN, Hayhoe K. Climate action for health and hope. BMJ 2021:374:n2100. doi: 10.1136/bmj.n2100 pmid: 34452923

2 COP26. Glasgow climate pact. 2021. https://unfccc.int/sites/default/files/resource/cma3_auv_2_cover\%20decision.pdf

3 Masson-Delmotte V, Zhai P, Pirani A, et al. Summary for policymakers. AR6 climate change 2021: the physical science basis. Intergovernmental Panel on Climate Change, 2021. https://www.ipcc.ch/report/ar6/wg1/\#SPM

4 Masson-Delmotte V, Zhai P, Pörtner HO, et al. Summary for policymakers. Special report: global warming of $1.5^{\circ} \mathrm{C}$. Intergovernmental Panel on Climate Change, 2018.

https://www.ipcc.ch/sr15/chapter/spm/

5 Romanello M, McGushin A, Di Napoli C, etal. The 2021 report of the Lancet Countdown on health and climate change: code red for a healthy future. Lancet 2021;398:1619-62. doi: 10.1016/S0140-6736(21)01787-6 pmid: 34687662

6 Ebi KL, Boyer C, Ogden N, etal. Burning embers: synthesis of the health risks of climate change.Environ Res Lett 2021;16:044042. doi: 10.1088/1748-9326/abeadd

7 WHO Global Health Observatory. Indicator 3.9.1: Mortality rate attributed to household and ambient air pollution (per 100000 population). https:/www.who.int/data/gho/data/indicators/indicator-details/GHO/ambient-and-household-air-pollution-attributable-death-rate-(per-100-000population)

8 COP26. The Glasgow climate pact. UN Climate Change Conference UK 2021. 2021. https://ukcop26.org/wp-content/uploads/2021/11/COP26-Presidency-Outcomes-The-Climate-Pact.pdf

9 Climate Action Tracker. Glasgow's 2030 credibility gap: net zero's lip service to climate action. 2021. https://climateactiontracker.org/documents/997/CAT_2021-11-09_Briefing_Global-Update_Glasgow2030CredibilityGap.pdf

102021 United Nations Framework Convention on Climate Change. World leaders kick start accelerated climate action at COP26. 2021. https://unfccc.int/news/world-leaders-kick-start-accelerated-climate-action-at-cop26

11 UN Climate Change Conference UK 2021. Glasgow leaders' declaration on forests and land use 2021 https://ukcop26.org/glasgow-leaders-declaration-on-forests-and-land-use/

12 WHO. Health and climate change survey report. 2021 https://www.who.int/publications/i/item/9789240038509

13 Magnan A, Christiansen L, Dale TW. Adaptation gap report 2020. 2021. https://backend.orbit.dtu.dk/ws/portalfiles/portal/238807594/AGR2020.pdf

14 WHO. COP26 health programme. 2021. https:/www.who.int/initiatives/cop26-health-programme

15 HealthyClimatePrescription. An urgent call for climate action from the health community ahead of COP26. 2021. https://healthyclimateletter.net/

16 Global Witness. Hundreds of fossil fuel lobbyists flooding COP26 climate talks. 2021 https://www.globalwitness.org/en/press-releases/hundreds-fossil-fuel-lobbyists-flooding-cop26climate-talks/

17 Climate Change and Health. COP26 special report on climate change and health. WHO, 2021 https://www.who.int/publications/i/item/cop26-special-report

18 Hamilton I, Kennard H, McGushin A, etal. The public health implications of the Paris Agreement a modelling study. Lancet Planet Health 2021:5:e74-83. doi: 10.1016/S2542-5196(20)30249-7 pmid: 33581069

19 Beagley J, van Daalen KR, Castillo BP, Jung L, Wyns A, Mattiisen JC. Assessing the inclusion of health in national climate commitments: towards accountability for planetary health. J Climate Change Health 2021:100085.doi: 10.1016/j.joclim.2021.100085. 